\title{
Matériaux, techniques de construction et datation entre Loire et Saône autour de l'an Mil
}

Projet collectif de recherche

\section{Christian Sapin}

\section{(2) OpenEdition}

\section{Journals}

Édition électronique

URL : https://journals.openedition.org/cem/762

DOI : 10.4000/cem.762

ISSN : 1954-3093

Éditeur

Centre d'études médiévales Saint-Germain d'Auxerre

Édition imprimée

Date de publication : 15 août 2005

ISSN : 1623-5770

\section{Référence électronique}

Christian Sapin, « Matériaux, techniques de construction et datation entre Loire et Saône autour de l'an Mil », Bulletin du centre d'études médiévales d'Auxerre | BUCEMA [En ligne], 9 | 2005, mis en ligne le 03 novembre 2006, consulté le 22 septembre 2022. URL : http://journals.openedition.org/cem/762 ; DOI : https://doi.org/10.4000/cem.762

Ce document a été généré automatiquement le 22 septembre 2022.

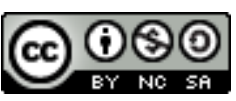

Creative Commons - Attribution - Pas d'Utilisation Commerciale - Partage dans les Mêmes Conditions 4.0 International - CC BY-NC-SA 4.0

https://creativecommons.org/licenses/by-nc-sa/4.0/ 


\title{
Matériaux, techniques de construction et datation entre Loire et Saône autour de l'an Mil
}

Projet collectif de recherche

\author{
Christian Sapin
}

1 Ce projet collectif de recherche lancé en 2003 avec des chercheurs de trois régions (Pays de la Loire, Centre et Bourgogne), est issu d'une constatation : quinze ans après le bilan national sur le paysage construit autour de l'an Mil, établi à l'occasion de l'anniversaire de l'avènement d'Hugues Capet, un certain nombre d'opérations ont été conduites ou sont en cours sur des sites monumentaux de cette période. Les méthodes de l'archéologie du bâti tendent aujourd'hui à reconsidérer dans leur nature et leur datation la plupart de ces sites. Il semble opportun ainsi de confronter les résultats de plusieurs travaux de terrain récents, tout en proposant des protocoles d'analyses et de relevés identiques pour mieux saisir des particularités techniques de ces constructions encore mal situées dans les $\mathrm{X}^{\mathrm{e}}$ et $\mathrm{XI}^{\mathrm{e}}$ siècles. L'apparition dans les régions Centre/Pays de la Loire/Bourgogne, souvent à l'intérieur ou au contact du futur domaine capétien, de nouveaux modes de constructions similaires, mais pas nécessairement contemporains, continue de nous interpeller. Certains de ces monuments sont depuis longtemps des références pour l'histoire de l'architecture. L'archéologie et ses méthodes doivent donc se préoccuper de ces enjeux et contribuer au renouvellement des connaissances en s'inscrivant en même temps dans des problématiques à l'échelle européenne. C'est en particulier le cas pour les travaux sur les briques et TCA (cf. ciavant le GDRE du CNRS), les techniques et méthodes de l'archéologie du bâti ${ }^{1}$, et, d'une manière générale, du projet, en cours de réalisation, de constitution d'un corpus européen des monuments antérieurs à l'an Mil.

2 À la suite des premières rencontres à Auxerre et Orléans, en 2004, les travaux du groupe ont porté, à partir des critères de datation, principalement sur les questions de mise en œuvre, d'étude des traces de taille (morphologie, rythme des frappes, orientations), et de la composition des mortiers. Ils ont confronté les analyses en cours 
de plusieurs sites considérés contemporains, comme Saint-Aignan d'Orléans, SaintÉtienne d'Auxerre ou Château-Landon. D'autres questions ont également été abordées, comme l'appareil mixte (alternance brique et pierre) et le rôle des modules comme critère, le phénomène des réemplois souvent surestimés et les possibilités da datation par archéomagnétisme ou thermoluminescences. Un programme croisé avec les ${ }^{14} \mathrm{C}$ des charbons contenus dans les mortiers se met en place sur plusieurs édifices concernés par le PCR. Par ailleurs, de nouvelles pistes de travaux ont été amorcées autour des évolutions des contreforts ou du caractère des claveaux appareillés dans les baies des constructions.

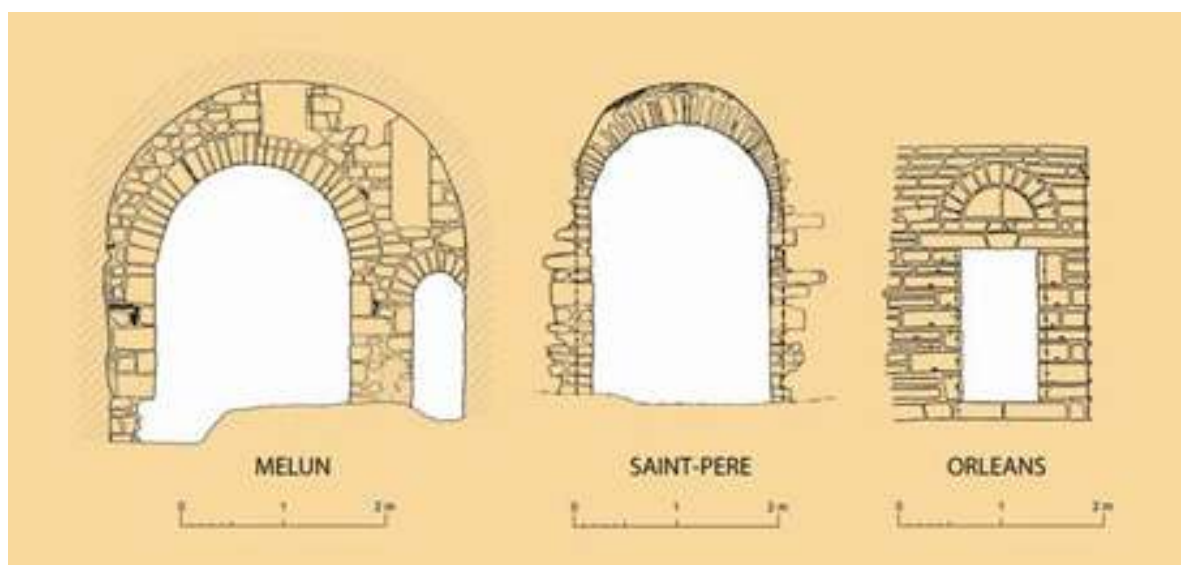

Exemples de baies (début XIe siècle).

\section{NOTES DE FIN}

1. Colloque : Les matériaux européens. Apport de l'archéométrie à l'archéologie du bâtiment, Liège 17-20 janvier 2005.

\section{INDEX}

Index géographique : France/Bourgogne, France/Centre, France/Pays-de-la-Loire

Mots-clés : datation, matériau de construction, technique de construction 